\title{
Chapter 28 \\ Urban and Peri-urban Agroforestry as Multifunctional Land Use
}

\author{
S. Borelli, M. Conigliaro, S. Quaglia, and F. Salbitano
}

\begin{abstract}
In this era of global changes, rapid urbanization rates, climate change impacts and growing socio-environmental concerns are negatively impacting on various aspects of urban life, such as human health and well-being, urban economy stability, biodiversity levels, land productivity and natural resources availability.

In this context, cities - having become the main centres of consumption and production worldwide - need to move towards more sustainable and resilient urban development models, considering novel approaches aimed at integrating grey and green infrastructure, economic growth and environmental concerns, knowledge diffusion and poverty and hunger eradication.

In this regard, the implementation of urban and peri-urban agroforestry (UPAF) systems - associated with the integration of urban food systems into urban planning - can greatly support the provision of ecosystem services to urban dwellers, thus contributing to the improvement of their livelihood through increased food and nutrition security, energy and fresh water availability, regulation of local climate, carbon sequestration, maintenance of genetic diversity, recreation opportunities and health improvement. In this sense, UPAF is emerging as a new urban practice addressed to promote sustainable land use as well as the integration between urban and rural development. However, its implementation in urban contexts presents several key challenges, such as land tenure conflicts, lack of integration with urban policies and plans and technical knowledge, as well as necessity of innovative governance models.
\end{abstract}

\footnotetext{
S. Borelli $(\bowtie) \cdot$ M. Conigliaro $\cdot$ S. Quaglia

Food and Agricultural Organization of United Nations (FAO),

Forestry Department (FO), Forest Policy and Resources Division (FOA), Rome, Italy

e-mail: simone.borelli@fao.org; michela.conigliaro@fao.org; stefano.quaglia@fao.org

F. Salbitano

Landscape Ecology Laboratory, Department of Agricultural, Food and Forest Systems Management (GESAAF), University of Florence, Florence, Italy

e-mail: fabio.salbitano@unifi.it
} 
In this context, the aim of this chapter is to outline, through a review of the relevant literature and case studies from both developed and developing countries, the benefits deriving from the implementation of UPAF systems and highlight how these practices can support the improvement of urban sustainability and resilience, particularly in terms of enhancement of provisioning, cultural, regulating and supporting ecosystem services.

Keywords Ecosystem services · Resilience - Sustainability · Urban agroforestry · Urban planning $\cdot$ Land tenure conflicts

\section{Introduction}

In the last decade, we have witnessed an urban transition ${ }^{1}$ : according to UN statistics, in 2007 for the first time, the world's urban population exceeded the rural one (Fig. 28.1). This figure is expected to keep rising and will reach $66 \%$ by 2050

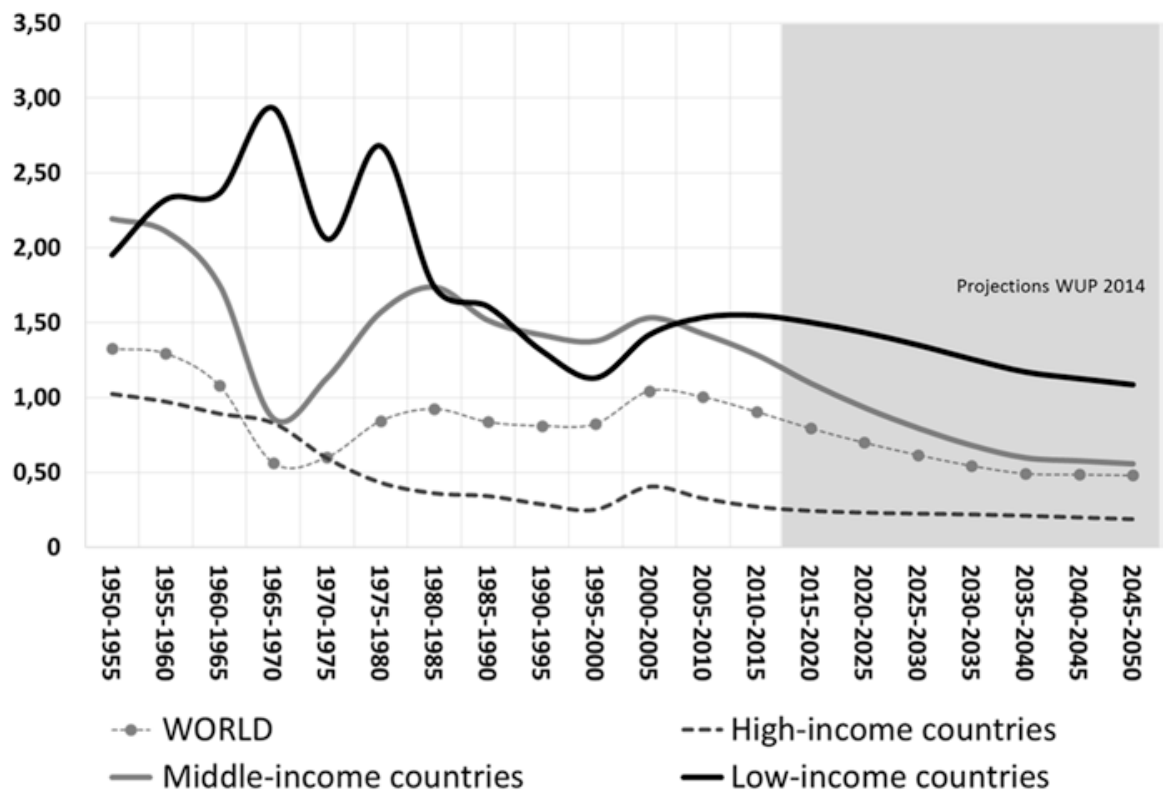

Fig. 28.1 Urbanization rate in development regions of the world (Source: United Nations, Department of Economic and Social Affairs, Population Division 2014)

\footnotetext{
${ }^{1}$ Firebaugh G. (1979) defines the urban transition as: "the reorganization of human society from being predominantly rural and agricultural to being predominantly urban and non-agricultural".
} 
(UN 2014). Even though urbanization is following different trends in the different regions, it must be considered and addressed as a global phenomenon.

In this context, rapid urbanization and ongoing global change - characterized by factors such as climate change, natural resource depletion, reliance on fossil fuels and pesticides, migration flows, volatile markets and growing wealth inequity - will contribute to a deepening food crisis and to an increase of inequality, poverty and dietary deficiency diseases in urban areas.

Even though cities cover less than $3 \%$ of world's surface, they consume $75 \%$ of world's natural resources. In fact, while they do offer many advantages to urban dwellers, by fragmenting and degrading natural habitat, reducing biodiversity, disrupting hydrological systems, altering energy flow and nutrient cycling, as well modifying people's lifestyles, they are also deeply altering the functioning of local and global ecosystems (Alberti 2005). These dynamics and the associated unsustainable land-use practices affect the provisioning of the key ecosystem services ${ }^{2}$ on which urban dwellers' livelihood depends: good quality water provision, soil fertility conservation, food production, climate regulation, air quality increase and wood fuel and timber provision.

To address the above issues, cities are increasingly called to work on the development of sound strategies and policies aimed to enhance the multifunctionality of urban and peri-urban green and blue infrastructure (sensu Borelli et al. 2015), towards the recovery and maximization of the benefits they can provide for a more sustainable and resilient model of urban development. In light of the increasing loss of political power of national states due to the impact of globalization and decentralization of government worldwide, cities' role in managing those issues is expected to become more and more relevant in the upcoming future.

In this regard, urban food systems and practices such as urban and peri-urban agriculture, forestry and agroforestry are among the most prominent strategies both in the Global North and South - to enhance food security and nutritional status (Clark and Nicholas 2013), protect and valorize natural capital and improve the sustainability and resilience of urban areas, contributing to fairer, healthier and more affordable urban food systems.

Especially at regional and local level, awareness regarding the importance of improving the urban food systems has only increased in the last decade. This change has been influenced by the new food equation (NFE) (Morgan 2009; Morgan and Sonnino 2010) that refers to various complex factors influencing the current food paradigm, such as the food crises of 2007-2008, the raise of food security and climate change as fundamental global concerns, the land-grabbing phenomenon in the developing world and the rapid expansion of urban areas. These factors have fostered the adoption, from local to national level, of novel approaches to the integration of food issues in the urban agenda, in both developed and developing economies, aiming to overcome the urban-rural dichotomy (Donadieu 2013), as demonstrated, for example, by the subscription in 2015 of the Milan Urban Food Policy Pact, an

\footnotetext{
${ }^{2}$ Daily GC (1997) defines ecosystem services as:" the conditions and processes through which natural ecosystems, and the species that make them up, sustain and fulfill human life".
} 
international protocol engaging 133 cities worldwide in the development of more sustainable, inclusive and resilient urban food systems.

As a result, in recent years, an increasing number of cities has been promoting urban and peri-urban agriculture (UPA) and forestry (UPF) practices in a variety of spaces at different scales - plot, farm and landscape - through their integration into local, regional and also national policy, with the aim of tackling different urban challenges such as food security, poverty, mitigation of and adaptation to the effects of climate change and prevention of non-communicable diseases, such as obesity and malnutrition (Wiskerke 2015).

Currently, widespread UPA practices are found in many cities worldwide. For example, Amsterdam has devoted over 350 ha of land to urban gardens for the production of fresh food and other goods for urban population (van Leeuwen 2010), while in Dar es Salaam, Tanzania, $90 \%$ of leafy vegetables and $60 \%$ of milk consumed in the city are produced within or around the urban area (Lee-Smith and Prain 2006).

UPF also has the potential, through sound planning and management of urban forests and trees, to provide a variety of environmental, sociocultural and economic benefits to city residents. Urban and peri-urban forests can play a relevant role in meeting new urban demands, as demonstrated by their increasing integration into urban planning by local authorities, through the adoption of strategies and policies establishing long-term targets to mitigate climate change effects and reduce disaster risks (Konijnendijk 2003; Nowak and Dwyer 2007; Clark and Nicholas 2013). For example, in 2007 the Mayor of London launched a climate change adaptation strategy aimed at increasing green spaces and trees cover in the city centre, in order to tackle flood risk and reduce the urban heat island effect (City of London Corporation 2010).

UPA and UPF have been often considered separately, especially in urban contexts. However, the deliberate combination of crops and trees (i.e. agroforestry) can result in more sustainable and resilient systems offering a wide range of ecosystem services, both in the global North and South (Nair 2007). Throughout history, there are numerous examples of diachronic and synchronic agroforestry and agrosilvopastoral systems, long before these terms were coined and the modern sense of the practices codified.

The aim of this chapter is to outline the benefits deriving from the implementation of urban and peri-urban agroforestry (UPAF) systems, highlighting how the related practices can support the improvement of urban sustainability and resilience, particularly in terms of enhancement of urban ecosystem services provision and urban communities' livelihood.

\section{Multifunctional Urban and Peri-urban Agroforestry Systems for Sustainable Land Uses}

Agroforestry is a dynamic and ecologically based land-use system, characterized by the integration between woody perennials (trees, shrubs, palms, bamboos, etc.) and crops and/or livestock on the same land management unit. The presence and/or use 
of woody species and crops/livestock can be simultaneous (synchronic agroforestry systems) or can be organized on a pluriannual basis (diachronic agroforestry systems). Proper management of these systems can optimize the biological, physical and ecological interaction of the different components, while achieving environmental, social and economic advantages for land users at all scales (Lundgren and Raintree 1982; Leakey 1996; Lassoie et al. 2009). Agroforestry is not an innovative practice or technology. Before being replaced by simplified and monoculture production systems, it was practiced for centuries, both in tropical and temperate regions, predominantly in rural areas and less frequently in urban contexts. In this regard, the key question is how did cities interact with these systems and what was their role if any in developing or introducing agroforestry systems in urban and periurban landscapes?

Trees have probably been a part of cities since their first development (Miller 2004). Since agriculture led to the first permanent settlements, it stands to reason that wild or domesticated plants were part of the community, including trees cultivated for food as well as for energy, medicines and other non-wood forest/tree products.

Food, wood and water supply relatively close to urban settlements was vital in ancient cities due to transport, safety and strategic reasons. Even if transportation networks developed quite early in human history, the opportunity of having at least a small amount of basic resources close or within the core city area has been decisive in the success or failure of urban experiences at least as much as the morphology and salubrity of sites and the presence water ways and harbour facilities for faster transportation. We should thus assume that the decision itself of placing permanent settlements in a particular location was often linked to the presence of tree species suitable for multiple uses and easily combined in multiple land uses. As example, the use of acorn meals is well rooted in native Americans' diet (Merriam 1918), and the presence of oaks was a crucial aspect in deciding the wintering sites for native Americans (McCarthy 1993).

The early Egyptians described trees being transplanted with balls of soil over 4000 years ago (Chadwick 1971) in the context of cities. Trees were valued for shade and aesthetics and were included in gardens around temples and palaces. It is likely that most trees were selected for their utilitarian value (fruit) as well as their beauty. The Hanging Gardens of Babylon are described in a number of ancient texts, and it is very likely that the structure of the gardens included several agroforestry systems (Miller 2004).

In the cities of ancient Greece, the lack of space and the geographical fragmentation of city-states (Polis) influenced the organization of peri-urban and urban landscapes in order to provide multiple resources where trees were associated to agricultural crops. Odysseus says, "Old man, you lack no skill at tending gardens. Everything is well-kept, and there is not a single plant, fig, vine, olive, pear, or garden that lacks your careful attention" (Odyssey 24.244-247. Translation by McCorie).

Dikaiopolis, the central character of Aristophanes' Akharnians, is an Attic farmer who has been forced to settle in the city during the Peloponnesian War 
(431-404 BC). During his prologue, Dikaiopolis explains how jarring it is for him to have to pay for everyday commodities. "I miss my home town", he says, "where I never had to buy charcoal, vinegar, or oil. The word 'buy' was not known there, but instead I produced everything myself'. Because they grew many different crops on their land, subsistence farmers like Dikaiopolis had little need for the market except during food shortages (MacDowell 1983).

Roman cities developed a wide typology of city gardens. Agroforestry systems were developed in urban and peri-urban areas. The gardens of ancient Pompeii are a tangible example of the organization of green spaces in a city, albeit provincial, 2000 years ago. Ancient Pompeii was not just made of roads and buildings: there were public and private green spaces, and every home, rich or modest, had its garden. Especially the suburban districts around the Amphitheatre, that experienced the inevitable transformations related to urban expansion, hosted a myriad of green areas with different uses: this meant that orchards and gardens for the production of fresh produce were concentrated in a relatively limited space. The archeobotanical remains of Vitis associated to tree species suggest the cultivation of vine trained upon elms, field maples and hornbeams in order to maximize the use of space for multiple resources production. Similarly, Juglans and Castanea archeobotanical remains in the neighbourhood of Neapolis associated to pollens of edible vegetable species suggest the presence of multipurpose agroforestry systems serving the city.

The walled medieval cities in Europe were surprising laboratories of agroforestry practices in urban areas. Despite the ever-told story of city gardens belonging to the nobles or rich families and generally cultivated for fruit, leisure and beauty, most of the cities experienced long periods of food and energy shortage because of the unsafety of the surrounding territories. Urban communities needed to find alternative solutions in term of producing food, energy and medicines within the city walls or in the immediate neighbourhoods of the city. As is still the case today, in the European medieval city, the garden was where the most fragile trees, the ones that require the most care were planted and it is there that new varieties are tested, acclimated and developed. The city garden could well have played a considerable role in the domestication of fruit trees. In parallel, the need of combining wood and food production required the development of structured practices of tree pollarding, topping and shredding combined with small horticultural or agricultural crops inside the city walls. Such practices were later exported to rural contexts maintaining a traditional way of managing both rural and urban trees.

The civilizations of Maya, Inca and Aztecs built large cities with monumental architecture, and they supported their cities with agriculture and agroforestry systems. Drawings and descriptions of pre-Columbian America suggest many native American tribes developed extensive agricultural communities, which included extensive gardens with planted trees (Box 28.1).

The recent renewed scientific interest in agroforestry is due to its potential contribution to sustainable development, thanks to its capacity of remaining productive and supporting a wide range of ecosystem services at the same time, as argued by Mbow et al. (2014), that have recognized the importance of implementing urban and peri-urban agroforestry practices as effective contribution towards the achieve- 


\section{Box 28.1 The Case of a Mayan City: Tikal (Lentz et al. 2014)}

Tikal has long been viewed as one of the leading polities of the ancient Maya realm. But how was the city was able to maintain its substantial population in the midst of a tropical forest environment up to the mid-9th century A.D. when Tikal was abandoned? The Late Classic Maya at Tikal practiced intensive forms of agriculture coupled with carefully controlled agroforestry and a complex system of water retention and redistribution. Because forests supplied essential resources, such as fuel, construction material, habitat for game, wild plant foods and a pharmacopoeia from medicinal species, agroforestry played a crucial role in the ancient Maya economy. By far, the heaviest demand on the forest was firewood needed for cooking and firing of ceramics. The production of lime (calcium oxide), an essential component of plaster, also required considerable fuel input. Wood required for construction and handicrafts also created an essential but less voluminous demand. The estimated wood quantities required annually for the maintenance of population at Tikal for fuel and construction was 42 million $\mathrm{kg} \cdot \mathrm{year}^{-1}$, approximately equal to the amount of wood available on a sustainable basis (39 million $\mathrm{kg} \cdot \mathrm{year}^{-1}$ ) from the Tikal upland and bajo forests. The Maya compensated for any shortages in forest productivity through the importation of pine wood and intensive techniques applied to a fixed plot agroforestry system that contributed up to $10 \%$ of the wood supply.

ment of a relevant part of Sustainable Development Goals (SDGs), particularly to the Goal 11: Making cities and communities more sustainable, resilient, and healthy.

Furthermore, urban agroforestry implementation is in line with the priorities included in the New Urban Agenda recently adopted in Quito, Ecuador, particularly those referring to the necessity of enhancing food security and nutrition for all, and improving environmental sustainability by promoting sustainable use of land and resources in urban areas.

In particular, the integration of agroforestry systems in urban contexts can consist in a variety of types such as riparian and forest buffers, greenways, windbreaks, urban gardens, roof gardens, homegardens and food forests (Mann 2014). These types, if properly planned and managed, can emphasize the multifunctionality of agroforestry systems, increasing their potential to play a relevant role in improving the sustainability and resilience of urban and peri-urban areas, by providing a variety of ecosystem services related to the enhancement of food and nutrition security and livelihood, by improving soil fertility and biodiversity, by regulating air and water quality as well as by supporting mitigation and adaptation to climate change effects.

Ecosystem services provided by UPAF can be categorized in four main types, as described by the Ecosystem Services Framework (MEA 2005; TEEB 2010):

1. Provisioning services are described as the products obtained from ecosystems. They can include food, freshwater, raw materials and medicinal resources. 
2. Cultural services are the immaterial benefits that people obtain from ecosystems such as recreation and mental and physical health, tourism, aesthetic values, spiritual enrichment and sense of place.

3. Regulating services act as regulators. These can provide benefits in terms of local climate and air regulation, carbon sequestration and storage, moderation of natural hazards, waste-water management, soil erosion prevention and pollination or biological control.

4. Supporting services are crucial to provide habitat for migratory species and to maintain the genetic diversity between species populations.

Below, a series of case studies illustrates the way in which the implementation of different types of UPAF practices can provide relevant ecosystem services to urban society and improve the sustainability and resilience of cities and towns.

\subsection{Provisioning Services}

In the case of provisioning services, urban and peri-urban agroforestry systems, even at plot scale, can play a significant role in supporting urban food and nutrition security, providing the conditions for growing fresh and affordable food for city dwellers (i.e. vegetables, fruits, mushrooms, berries, aromatic spices) and fodder for animal husbandry (i.e. leaves, seeds, sprouts), as well as in enhancing livelihood security from sale of items produced by urban farmers (i.e. food, fodder, timber, plants oil, medicinal plants), especially in low-income countries (Salbitano et al. 2015).

Agroforestry systems in urban areas can also significantly contribute to the sustainable management of water. In fact, trees and vegetation cover, by helping to capture, filter and store water resources, plays a vital role both in supplying highquality water and in regulating its availability for urban dwellers (FAO 2016).

In addition, agroforestry practices can be an important source of raw materials for construction, especially in regions where there is limited timber available and of energy, providing the wood fuel on which $38 \%$ of world's population still relies for cooking and heating, especially in developing Asia and sub-Saharan Africa, as estimated by the International Energy Agency (2015).

\subsubsection{Tropical Homegardens and Food Security}

Tropical homegardens ${ }^{3}$ (Fig. 28.2) are recognized as ecologically and socially sustainable agroforestry systems. This is due to their ecological characteristics - such as efficient nutrient cycling, high levels of biodiversity and limited exogenous inputs

\footnotetext{
${ }^{3}$ Kumar and Nair (2004) define tropical homegarden as: "intimate, multistory combinations of various trees and crops, sometimes in association with domestic animals, around the homestead".
} 


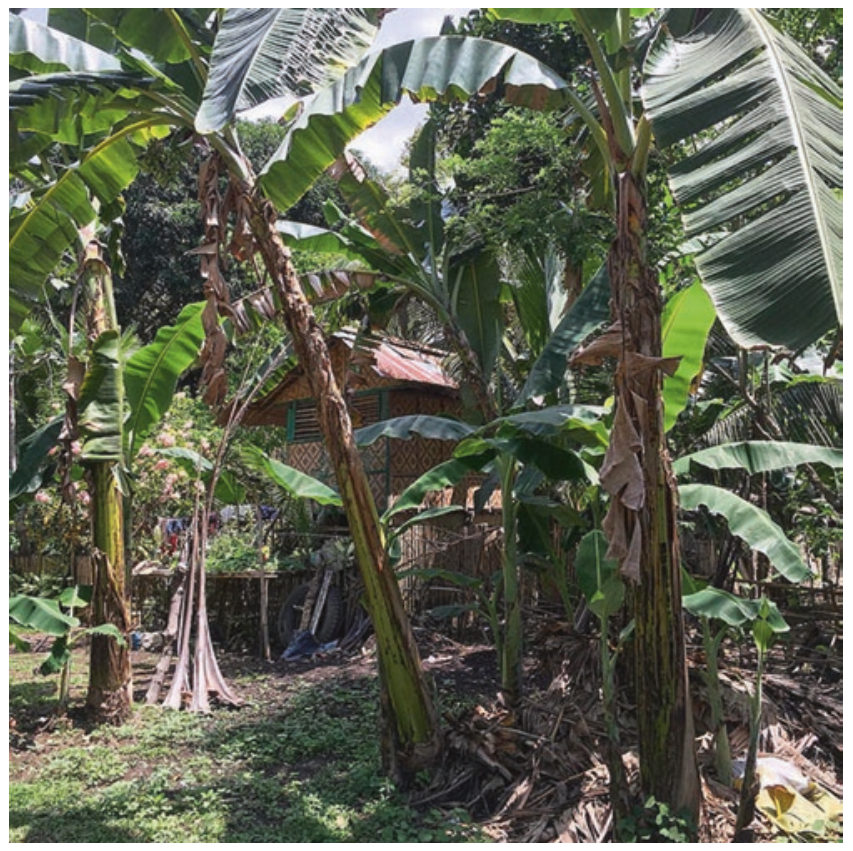

Fig. 28.2 Tropical homegarden in the Philippines (Source: Thomas Galvez 2016) https://www. flickr.com/photos/69031678@N00/27775415291

required, as well as soil protection and enrichment (Torquebiau 1992; Jose and Shanmugaratnam 1993; Gliessman 1998; Méndez et al. 2001) - and their capacity of providing a variety of socio-economic benefits to the local population, contributing to food and nutrition security, energy needs and livelihood enhancement (Lok 1998; Kumar and Nair 2004; Peyre et al. 2006).

Homegardens in tropical regions represent a well-established land-use system, even though in recent times they are increasingly threatened by growing urbanization, "agrodeforestation", (Thaman 1992) and increasing dependence on imported food and fuels (Thaman 1988). However, tropical homegardens still play a key role in enhancing food security of urban and peri-urban dwellers (Kumar and Nair 2004). In fact, as argued by Montagnini (2006), these practices can contribute to local food security in several ways, by fostering direct access to quality and healthy food; enhancing family income, thanks to savings on food bills and on generation of additional income from sale of garden production; and providing food products year-round, especially during periods of food scarcity.

For example, in both Pacific and Caribbean islands, homegardening allows to address food and nutrition security through the provision of local and traditional fruits (mango, avocado, oranges, lemon, papaya, etc.), vegetables (tomatoes, eggplant, bean, etc.) and also some herbs (oregano, coriander, rosemary basil and mint) 
(USDA 2015). One of the most widely cited examples is Havana, Cuba, where, as reported by Altieri et al. (1999), in 1996, homegardens provided a significant amount of fresh food to urban population, including 8500 tons of agricultural produce, 7.5 million eggs and 3650 tons of meat.

In addition, multistorey homegardens can provide medicinal plants to the families and communities that maintain them, both for subsistence and marketing purposes. These homegardens are characterized by different layers of plants of medicinal value, including a ground layer $(0-1 \mathrm{~m})$, generally constituted by herbs, vines or climbers in combination with vegetables and spices, and a second (1-3 m) and upper layers (>10 m) made up by shrubs and trees (Wezel and Bender 2003; Rao and Rao 2006). The relevance of traditional herbal medicines is witnessed by their widespread use in developing countries, especially in Africa where up to $80 \%$ of population is still dependent on them (WHO 2002). Furthermore, if not directly consumed, medicinal resources can be sold for generating additional income. The sale of medicines of natural origin has an estimated global market of US\$57 billion per year (Kaimowit 2005).

\subsection{Peri-urban Agroforestry and Livelihood Enhancement in Nigeria}

Several authors (Drescher et al. 2006; Yamada and Osaqui 2006; Kumar and Nair 2004) have observed how marketing-oriented homegardening as an opportunity to generate additional cash income is increasingly widespread, particularly in the Global South.

A study by Odurukwe (2004) has demonstrated the relevant role of agroforestry practices in peri-urban cities of Abia State, Nigeria, namely, Uzuakoli, Obehie and Isuikwuato. In these cities, one of the main purposes for practicing multistorey homegardening is the chance for inhabitants to improve their livelihoods through income generation. The interviews, involving 180 randomly selected households, highlighted the great contribution of agroforestry in enhancing households' livelihood through the sale of homegardening products, with $75 \%$ of the interviewed reporting to have increased their income from selling goods such as fruits, food crops, vegetables, leaves, seeds, bark, fuelwood, etc. In this context, 17\% of respondents reported to an additional annual income of between USD 180 and 270, 52\% declared an average amount of between USD 90 and 180, and only $31 \%$ of households earn around USD 90. However, despite the great potential of peri-urban agroforestry for generating additional cash income, in Abia State, this land use is limited by the lack of sound planning, management and monitoring, in order to avoid conflicts with other land uses and problems related with land ownership. 


\subsection{Cultural Services}

In addition to the production of material goods (food, fibre and other non-wood forest products), UPAF can also provide a variety of immaterial services. As argued by Barthel et al. (2010, 2013), agroforestry practices in urban areas can help communities maintain "socio-ecological memory" described as "the combined means by which knowledge, experience and practice of ecosystem management are captured, stored, revived, and transmitted through time"; this brings an important educational value to urban dwellers, raising awareness of the importance of links between urban ecosystem services and human well-being (Camps-Calvet et al. 2016), helping to overcome the so-called "extinction-of-experience" (Pyle 1978) or "global generational amnesia" (Miller 2005) and connecting older and younger generations.

Moreover, urban agroforestry practices are also recognized as important source of psychological, health and social benefits for urban dwellers and city users, contributing to stress reduction (Ulrich 1981), providing a sense of peacefulness, beauty and freedom (Kaplan 1983) and also fostering social interaction and integration among residents (Coley et al. 1997). Finally, in terms of aesthetic, historical and recreational values, agroforestry systems can provide a more pleasant and liveable urban landscape by offering different colours, shapes and textures that vary according to season and weather conditions (Miller 1997), as well as increase city's attractiveness as a tourist destination (Chiesura 2004).

\subsection{Beacon Food Forest}

For the past two decades, the Seattle Department of Neighborhoods has provided funding for green infrastructure programs, focusing particularly on the provision of environmental services and food production, through the implementation of street tree planting and other greening projects around the city. More recently, the Department shifted its vision in order to incorporate urban forests into the city as a whole (McLain et al. 2012). The development of the Beacon Food Forest (Fig. 28.3), a community-driven food forest, started in 2009 combining aspects of native habitat rehabilitation and edible forest gardening. The forest was to cover a 7-acre public land in the Beacon Hill neighbourhood, an area characterized by high levels of cultural diversity.

Initially designed by four students as final project for a permaculture design course, the food forest concept was later presented both to the community and to Seattle City agencies and become part of the Seattle Department of Neighborhoods P-Patch Community Garden Program, benefitting from expert support and public funds for the community design process and the subsequent implementation (Seattle Department of Neighborhoods 2016). Thanks to the community involvement and the local authorities' support, phase one of the project started in 2012 and was con- 


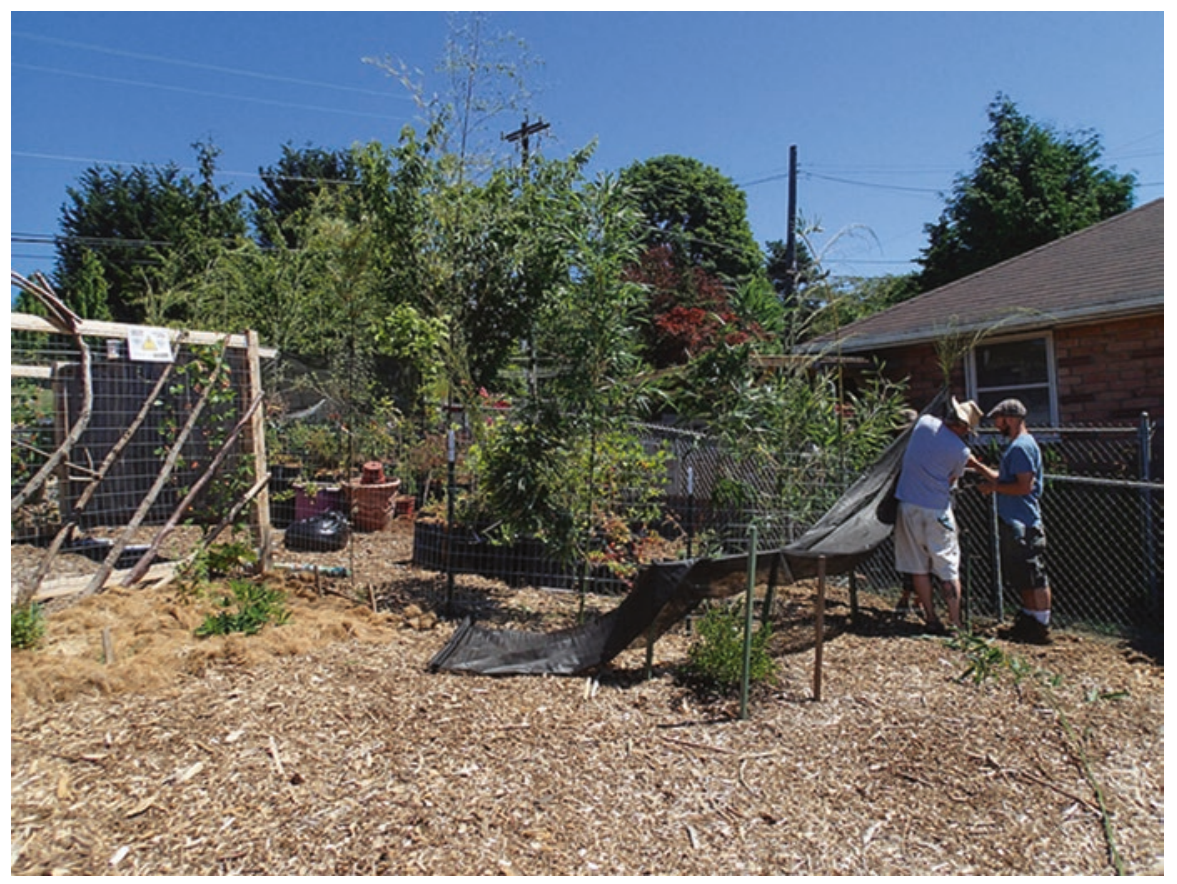

Fig. 28.3 The beacon food forest (Source: Flickr/Wright J 2013) https://www.flickr.com/photos/ eakspeasy/9180679958/in/photolist-eZ57tK-dgp3SZ-dgp3Wk-eN4F8e-eZgsbf-dgp3wZ-dgp2YFeZgma1-eZ549g-eZgr4G-eZ4WSp-eZgoiu-dgp3Nx-dgp58N-dgp2b8-eZguBy-eZgsyw-eN4F1ZeZgu7f-eZgnvW-eZ54F4-eZ51cc-eZgtNy-eZ4YUe-eZ4WqP-eN4BMc-eNg6k5-eh

cluded in 2014, initially covering an area of 0.8 ha that was made available by the landowner, Seattle Public Utilities, with the possibility of expanding the project in the future according to the interest and support of the community.

The Beacon Food Forest aims to foster community and social justice building through an integrated agroforestry woodland food system including several layers with fruit and nut trees (providing sustenance and shade), forming the upper level, and berry shrubs, perennials and annuals (for free gleaning and picking), forming the ground layer. In addition, the project includes a community garden to allow families to grow their own food, a gathering plaza used for celebration and educational activities and kids' area for education and play (Beacon Food Forest 2016).

Indeed, besides the improvement of local food security and ecosystem, Beacon Food Forest's main goal is to provide work and educational opportunities for students and disadvantaged groups, while at the same time strengthening community connections, raising environmental awareness and improving knowledge on food forest principles and permaculture practices. 


\subsection{Regulating Services}

By playing a relevant role as a regulator of ecosystem processes, UPAF contributes to the environmental sustainability and resilience of cities. By providing shade and increasing evapotranspiration, properly planned and placed agroforestry systems can significantly mitigate the urban heat island effect and reduce the energy demand of buildings for heating and cooling. Moreover, agroforestry is increasingly recognized as climate-smart practice (FAO 2013) for its capacity of regulating local climate by above and below ground carbon sequestration and storage, although its carbon capture and sequestration potential are influenced by several variables such as species composition, age structure, climate context and management system (Jose 2009).

Water cycle optimization and storm water runoff regulation are also important services provided by the integration of trees and crops in urban areas. Furthermore, by intercepting rainfall, tree and vegetation cover helps in mitigating soil loss and soil erosion. Acting as filters, urban agroforestry patches help remove pollutants from the atmosphere improving air quality through the absorption of ozone, sulphur dioxide, nitrogen dioxide, carbon monoxide and particulate matter (Nowak 1994; Escobedo et al. 2008).

\subsubsection{Multifunctional Agroforestry for Climate Change Adaptation in Bobo-Dioulasso}

According to the 2006 census (INSD 2007), Bobo-Dioulasso, with a population of nearly 500,000 inhabitants, a growth rate of 7\%, and an extension of 160,000 ha of which approximately $19 \%$ is built environment, is the second largest city of Burkina Faso, after its capital, Ouagadougou. The city, as many others in sub-Saharan Africa, is experiencing a rapid population growth associated with the fast transformation of rural to urban land use, resulting in the increase of impervious surfaces and vegetation reduction. These dynamics, coupled with climate change effects, are negatively impacting on rainfall patterns, land surface temperatures - which increased by about 6\% in the 1991-2013 period (Di Leo et al. 2016) - as well as on agricultural and livestock productivity.

Bobo-Dioulasso plays a key role in the national economy. It is recognized as the economic capital of the country because of the relevance of its textile industry and agricultural activities and production. In this light, the impacts of climate change, negatively affecting the natural resources that are essential for industrial and agriculture production, could jeopardize not only the local, regional and national development but also the social and political stability of the country (UN-Habitat 2014; Ricci et al. 2015). In order to address the negative impacts of urbanization and climate change, the Bobo-Dioulasso municipality has promoted multifunctional urban and peri-urban agroforestry on urban greenways as a climate change mitigation and adaptation strategy (Fig. 28.4). 


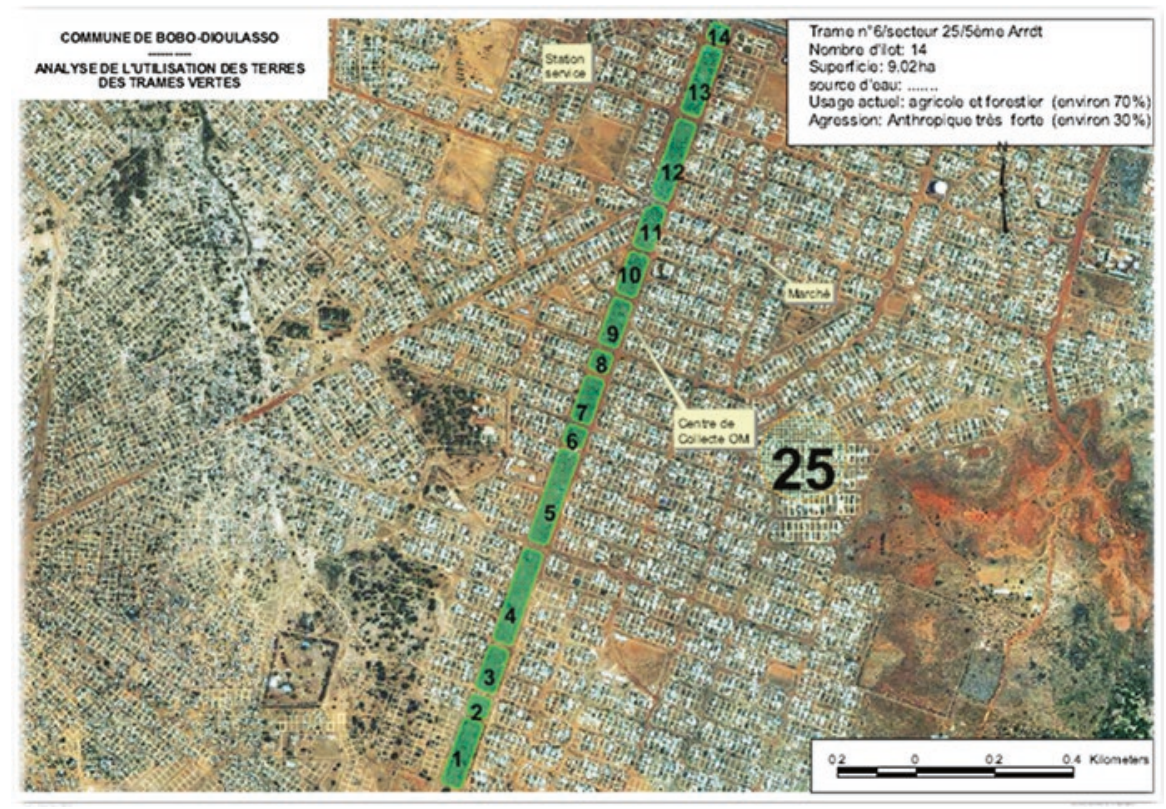

Fig. 28.4 Bobo-Dioulasso greenways strategy (Source: Commune de Bobo Dioulasso 2014)

This strategy is one of the outcomes of the UN-Habitat Cities and Climate Change Initiative (CCCI) in Bobo-Dioulasso. In particular, by carrying out a participative and consultation process aimed at identifying the current and future climate risks for the city and involving a wide range of local stakeholders, the CCCI has defined and adopted a Participatory Climate Risk Management Framework (PCRMF), which was operationalized through the development of the greenways project, supported by UN-Habitat and coordinated by RUAF (Ricci et al. 2015).

Vacant lands within the city were transformed into green corridors through the establishment multifunctional agroforestry systems aimed at mitigating the urban heat island effect and reducing surface runoff, as well as enhancing the resilience of urban dwellers by providing additional food and income sources (Sy et al. 2014). By 2012, eight greenways covering approximately 60 ha were established in the city. These green corridors, connecting the city with its peri-urban forests, provide multifunctional land uses and several functions to urban dwellers, such as forest production, market gardening and provision of recreational and educational spaces (UN-Habitat 2014). They represent a model of sustainable urban development, tackling climate change and enhancing urban ecosystem services in and around the city. 


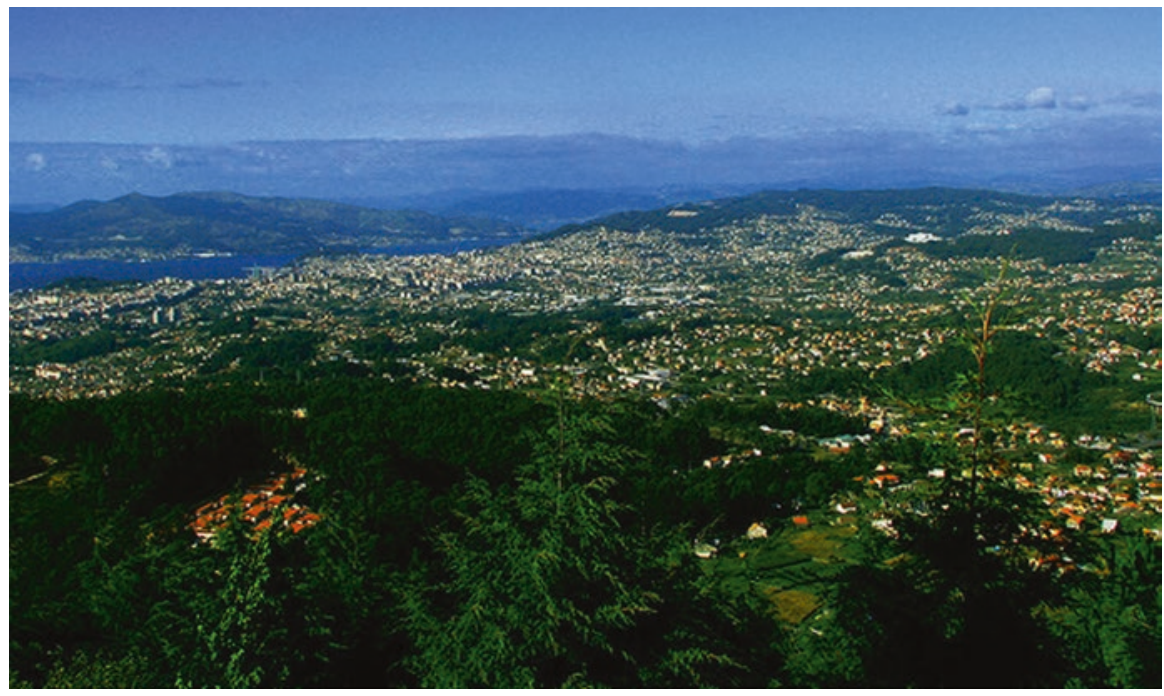

Fig. 28.5 View of city of Vigo (Source: Flickr/Foxspain Fotografìa 2008) https://www.flickr.com/ photos/foxspain/3216229210/in/photolist-5Ud1TL-dJcxX3-8LX4nE-PG2T2-orBkss7aqBmf-otrgd1-pFHKrw-7aqBmm-8d6SjC-8A8ByC-4pYSPb-8xRWmn-pFHLnE-ppeYE5otrfqQ-5V7Tje-dzTfrH-oc9p9N-7Ji9uM-7Jn2U3-7wCaoB-orBgN3-o6ZBK-otre5o-otr9G527w9Sk-ocaFh

\subsection{Supporting Services}

Urban and peri-urban agroforestry plays an important role in providing habitat for migratory species and species that can tolerate a certain level of disturbance. It can help reduce the conversion of natural habitat by providing a more productive, sustainable alternative to traditional agricultural systems. By creating corridors between habitat remnants, it can support the conservation of area-sensitive plant and animal species, and finally it can help conserve biological diversity by preventing the degradation and loss of surrounding habitats (Jose 2009).

\subsubsection{City Region of Vigo: Multifunctional Management of Common Lands}

In the city region of Vigo, Galicia, Spain, a major portion of the metropolitan area consists of green infrastructure components (Fig. 28.5), including public parks, private land lots and privately owned but commonly managed areas, the so-called Commons. In the case of Vigo, according to traditional land use, the Commons are located in mountain area, called Monte, and characterized by the presence of forests, scrubs and bushes. In the city region of Vigo, there are approximately 100 Commons managing $32 \%$ of the total metropolitan area. 
The Commons way of managing land, which was oriented to a multifunctional approach to agriculture, agroforestry, silviculture and animal husbandry, was dramatically changed during Franco's dictatorship (1939-1975) to initiate afforestation campaigns by using mainly Eucalyptus. In the last two decades, some Commons in the city region are recovering their multifunctional use, as well as the diversity and variety of landscape mosaic. The Commons of Vinicios (10 min to the centre of Vigo) implemented several projects for biodiversity and active landscape conservation, forest food production and cultural and social issues. Re-establishing former agroforestry systems, either formal or informal, constitutes one of the key steps in restoring the multifunctional structure of the landscape, including the potential of peri-urban agroforestry to provide supporting ecosystem services (Garcia et al. 2015).

\section{Key Challenges}

As many other land uses, urban agroforestry faces a number of challenges for implementation that are very similar to those encountered by urban agriculture and urban forestry. In particular, when considering the establishment or the conservation of agroforestry systems in urban settings, it is important to be aware of the following issues:

Land Tenure A well-defined land tenure framework is essential for enhancing the potential of UPAF in any given location. Indeed, people are usually unwilling to plant trees on land for which they do not have guaranteed long-term access, either as owners or leaseholders. Land-use conflicts are often more severe due the pressure of urban growth, so it is essential to establish clear rights on the land and robust platforms for conflict management.

Urban Planning Urbanization has caused major changes in land use and landscapes in and around cities. Comprehensive urban plans should support UPAF and provide frameworks for implementing land-use regulations in an effective and transparent manner. They should also ensure that planning of green spaces, including areas that are designated for urban agroforestry, receives equal attention in the urban planning process as the elements of the built environment are viewed as key elements of the urban fabric, providing the city with the ecosystem services listed above.

Technical Knowledge Agroforestry systems are more knowledge intensive than ordinary agriculture systems in view of their relatively higher complexity. The information available to agroforestry practitioners in urban areas could be increased through extension services and field schools, which could be provided by local organizations (such as farmer associations), and through the provision of e-learning, toolkits, plot demonstrations and farmer-farmer exchanges. 
Governance The governance of green infrastructures requires that planning departments have the necessary technical skills and knowledge to include urban agroforestry in the overall planning process. It is also essential that the community has the capacity to act on the opportunities provided by the governance process. This may be the case in only some groups or for certain individuals. In any case, innovative urban agroforestry governance requires education and capacity building. Depending on the local conditions, governance can follow different models ranging from full self-governance of land users to a more comprehensive governmental regulatory framework.

These of course are only some of the challenges that will be faced in establishing urban agroforestry systems. Other possible issues to be addressed include lack of intersectoral coordination, access to markets, food safety as well as access to credit.

\section{Conclusions/Way Forward}

From the experiences described above, it is quite apparent that UPAF is a widespread practice in both low-income countries and as well as in the so-called developed world. UPAF, like urban agriculture and urban forestry, promotes inclusiveness in terms of involving experts, policy makers and communities, and it is crucial to ensure that any initiative is fully integrated with other comprehensive approaches to natural resources management and land use within the city boundaries, at the urban fringe and at the urban-rural interface. These include urban greening, green infrastructure planning, nature conservation, forestry and agriculture. All these elements can contribute to improve urban living conditions and livelihoods and can help cities "farm for the future". Land should not be seen as a space for conflict between urban forestry, urban agriculture, urban agroforestry and urban recreation but should rather be the space to create integrated opportunities for maximizing benefits to urban dwellers.

More effort is needed in identifying the most suitable combination of productive, environmental and socio-economic functions and in designing the most effective mosaic of "green" land uses suited to the different conditions of individual cities.

\section{References}

Alberti M (2005) The effects of urban patterns on ecosystem function. Int Reg Sci Rev 28(2):168-192

Altieri MA, Companioni N, Cañizares K, Murphy C, Rosset P, Bourque M, Nicholls CI (1999) The greening of the "barrios": urban agriculture for food security in Cuba. Agric Hum Values 16(2):131-140

Barthel S, Folke C, Colding J (2010) Social-ecological memory in urban gardens - retaining the capacity for management of ecosystem services. Glob Environ Chang 20(2):255-265 
Barthel S, Parker J, Ernstson H (2013) Food and green space in cities: a resilience lens on gardens and urban environmental movements. Urban Stud 52(7):1321-1338

Beacon Food Forest (2016) Beacon Food Forest Permaculture Project. Webpage. Available at: http://beaconfoodforest.org/

Borelli S, Chen Y, Conigliaro M, Salbitano F (2015) Green infrastructure: a new paradigm for developing cities. Technical paper at the XIV World Forestry Congress, Durban, South Africa, 7-11 September 2015

Camps-Calvet M, Langemeyer J, Calvet-Mir L, Gómez-Baggethun E (2016) Ecosystem services provided by urban gardens in Barcelona, Spain: insights for policy and planning. Environ Sci Pol 62:14-23

Chadwick LC (1971) 3000 years of arboriculture: past, present and the future. Arborists News 36(6):73-78

Chiesura A (2004) The role of urban parks for the sustainable city. Landsc Urban Plan 68(1):129-138

City of London Corporation (2010) Rising to the challenge: the city of London climate change adaptation strategy. First published May 2007, revised and updated January 2010. London, City of London Corporation. Available at: https://www.cityoflondon.gov.uk/services/environmentand-planning/sustainability/Documents/climate-change-adaptation-strategy-2010-update.pdf

Clark KH, Nicholas KA (2013) Introducing urban food forestry: a multifunctional approach to increase food security and provide ecosystem services. Landsc Ecol 28(9):1649-1669

Coley RL, Sullivan WC, Kuo FE (1997) Where does community grow? The social context created by nature in urban public housing. Environ Behav 29(4):468-494

Daily GC (1997) Nature's services: societal dependence on natural ecosystems. Island, Washington, DC

Di Leo N, Escobedo FJ, Dubbeling M (2016) The role of urban green infrastructure in mitigating land surface temperature in Bobo-Dioulasso, Burkina Faso. Environ Dev Sustain 18:373-392

Donadieu P (2013) Campagne Urbane. Una proposta di paesaggio per la città. Donzelli, Roma

Drescher AW, Holmer RJ, Iaquinta DL (2006) Urban homegardens and allotment gardens for sustainable livelihoods: management strategies and institutional environments. In: Tropical homegardens. Springer, Dordrecht, pp 317-338

Escobedo FJ, Wagner JE, Nowak DJ, De la Maza CL, Rodriguez M, Crane DE (2008) Analysing the cost effectiveness of Santiago, Chile's policy of using urban forests to improve air quality. J Environ Manag 86(1):148-157

FAO (2013) Advancing agroforestry on the policy agenda: a guide for decision-makers. In: Place F, Gauthier M (eds). Food and Agriculture Organization of the United Nations, Rome. Available at: http://www.fao.org/3/a-i3182e.pdf

FAO (2016) Guidelines on urban and peri-urban forestry, by Salbitano F, Borelli S, Conigliaro M, Chen Y. FAO Forestry paper no. 178. Rome, Food and Agriculture Organization of the United Nations, Rome. Available at: http://www.fao.org/3/a-i6210e.pdf

Firebaugh G (1979) Structural determinants of urbanization in Asia and Latina America, 1950 1970. Am Soc Rev 44:199-215

Garcia LD, Fernàndez XS, Swagemakers P (2015) Edible landscape: food and services from common-land use in the Vigo city region, in Urban Agriculture Magazine, vol 29, pp 54-56

Gliessman SR (1998) Agroecology: ecological processes in sustainable agriculture. Ann Arbor Press, Chelsea/Michigan

INSD-Institut National de la Statistique et de la Démographie (2007) Resultants preliminares du recensement général de la population et de l'habitation (RGPH) de 2006. Burkina Faso, $51 \mathrm{p}$

International Energy Agency (2015) 'World energy outlook'. Available at: http://www.worldenergyoutlook.org/resources/energydevelopment/energyaccessdatabase/

Jose S (2009) Agroforestry for ecosystem services and environmental benefits: an overview. Agrofor Syst 76(1):1-10

Jose D, Shanmugaratnam N (1993) Traditional homegardens of Kerala: a sustainable human ecosystem. Agrofor Syst 24(2):203-213 
Kaimowit D (2005) Forests and human health: some vital connections. Swedish CGIAR, Bogor

Kaplan R (1983) The analysis of perception via preference: a strategy for studying how the environment is experienced. Landscape Plann 12(2):161-176

Konijnendijk CC (2003) A decade of urban forestry in Europe. Forest Policy Econ 5(2):173-186

Kumar BM, Nair PR (2004) The enigma of tropical homegardens. In: New vistas in agroforestry. Springer, Dordrecht, pp 135-152

Lassoie J, Buck L, Current D (2009) The development of agroforestry as an integrated land use management strategy. In: Garrett HE (ed) North American agroforesty: an integrated science and practice. America Society of Agronomy, Madison, pp 1-23

Leakey RRB (1996) Definition of agroforestry revisited. Agrofor Today 8(1):8-10

Lee-Smith D, Prain G (2006) Understanding the links between agriculture and health. Focus 13. International Food Policy Research Institute, Washington, DC

Lentz DL, Dunning NP, Scarborough VL, Magee KS, Thompson KM, Weaver E, Carr C, Terry RE, Islebe G, Tankersley KB, Grazioso Sierra L, Jones JG, Buttles P, Valdez F, Ramos Hernandez CE (2014) Forests, fields, and the edge of sustainability at the ancient Maya city of Tikal. PNAS 111(52):18513-18518

Lok R (ed) (1998) Huertos caseros tradicionales de America Central: caracteristicas, beneficios e importancia, desde un enfoque multidisciplinario. CATIE/AGUILA/IDRC/ETC, Turrialba

Lundgren BO, Raintree JB (1982) Sustained agroforestry. In: Nestel B (ed) Agricultural research for development: potentials and challenges in Asia. ISNAR, The Hague, pp 37-49

MacDowell DM (1983) The nature of Aristophanes' 'Akharnians'. Greece \& Rome 30(2):143-162

Mann S (2014) Urban agroforestry: connecting agroecology, permaculture, urban forestry and urban agriculture with agroforestry, ecological principles of agroforestry. University of Missouri, Columbia

Mbow C, Van Noordwijk M, Prabhu R, Simons T (2014) Knowledge gaps and research needs concerning agroforestry's contribution to sustainable development goals in Africa. Curr Opin Environ Sustain 6:162-170

McCarthy H (1993) managing oaks and the acorn crop. In: Thomas CB, Anderson K (eds) Before the wilderness: environmental management by native Californians. Ballena Press, Menlo Park

McLain R, Poe M, Hurley PT, Lecompte-Mastenbrook J, Emery MR (2012) Producing edible landscapes in Seattle's urban forest. Urban For Urban Green 11(2):187-194

MEA (2005) Millennium ecosystem assessment findings, Washington, DC

Méndez VE, Lok R, Somarriba E (2001) Interdisciplinary analysis of homegardens in Nicaragua: micro- zonation, plant use and socioeconomic Importance. Agrofor Syst 51(2):85-96

Merriam CH (1918) The Acorn, a possibly neglected source of food. Natl Geogr Mag 34(2):129-137

Miller RW (1997) Urban forestry: planning and managing urban greenspaces, 2nd edn. PrenticeHall, Englewood Cliffs

Miller RW (2004) Urban forestry: history and introduction. In: Konijnendijk CC, Schipperijn J, Hoyer KK (eds) Forestry serving urbanised societies. Selected papers from a conference jointly organized by IUFRO, EFI and the Danish Centre for Forest, Landscape and Planning - KVL in Copenhagen, Denmark, 27-30 August 2002. Vienna, IUFRO, 2004. - 407 p - (IUFRO world series vol 14)

Miller JR (2005) Biodiversity conservation and the extinction of experience. Trends Ecol Evol 20(8):430-434

Montagnini F (2006) Homegardens of Mesoamerica: biodiversity, food security, and nutrient management. In: Kumar BM, Nair PKR (eds) Tropical homegardens: a time-tested example of sustainable agroforestry. Springer, Dordrecht, pp 61-84

Morgan K (2009) Feeding the city: the challenge of urban food planning. Int Plan Stud 14(4):341-348

Morgan K, Sonnino R (2010) The urban foodscape: world cities and the new food equation. Camb J Regions, Econ Soc, rsq007

Nair PK (2007) The coming of age of agroforestry. J Sci Food Agric 87(9):1613-1619

Nowak DJ (1994) Understanding the structure of urban forests. J For 92:42-46 
Nowak DJ, Dwyer JF (2007) Understanding the benefits and costs of urban forest ecosystems. In: Kuser JE (ed) Urban and community forestry in the northeast. Springer, New York, pp 25-46

Odurukwe S (2004) Agroforestry in Peiurban Cities of Abia State, Nigeria. In Urban Agriculture Magazine, no 13, RUAF, Leusden. Available at: http://www.ruaf.org/sites/default/files/Agrofo restryinPeriurbanCitiesofAbiaState,Nigeria_1.pdf

Peyre A, Guidal A, Wiersum KF, Bongers F (2006) Dynamics of homegarden structure and function in Kerala, India. Agrofor Syst 66(2):101-115

Pyle RM (1978) The extinction of experience. Horticulture 56:64-67

Rao MR, Rao BR (2006) Medicinal plants in tropical homegardens. In: Kumar BM, Nair PKR (eds) Tropical homegardens. Springer, Dordrecht, pp 205-232

Ricci L, Sanou B, Baguian H (2015) Climate risks in West Africa: Bobo-Dioulasso local actors' participatory risks management framework. Curr Opin Environ Sustain 13:42-48

Salbitano F, Borelli S, Sanesi G (2015) Urban forestry and agroforestry. In: de Zeeuw H, Drechsel $\mathrm{P}$ (eds) Cities and agriculture: developing resilient urban food systems. Routledge - Earthscan, Oxon, pp 285-311

Seattle Department of Neighborhoods (2016) Beacon food forest. Webpage. Available at: http://www. seattle.gov/neighborhoods/programs-and-services/p-patch-community-gardening/p-patch-list/ beacon-food-forest

Sy M et al (2014) Multiple use of green spaces in Bobo-Dioulasso, Burkina Faso. Urban Agric Mag 27

TEEB (2010) The economics of ecosystems and biodiversity ecological and economic foundations. In: Kumar P (ed). Earthscan, London/Washington, DC

Thaman RR (1992) Agrodeforestation as a major threat to sustainable development. In: Thistlethwaite R and Votaw G. (eds.)

Thaman RR (1988) Environmental issues in the Pacific Islands: constraints to sustainable island development, Pacific Issues 1. Pacific Circle Consortium, Woden, pp 1-77

Torquebiau E (1992) Are tropical agroforestry homegardens sustainable? In: Agric Ecosyst. Environ, vol 41, pp 189-207

Ulrich RS (1981) Natural versus urban sciences: some psycho-physiological effects. Environ Behav 13:523-556

UN-Habitat (2014) The State of Africa Cities 2014: re-imaging sustainable urban transition. Nairobi, United Nations Human Settlements Programme. Available at: http://unhabitat.org/ books/state-of-african-cities-2014-re-imagining-sustainable-urban-transitions/

United Nations (2014) World Urbanization Prospects. The 2014 Revision. Highlights. New York. Available at: http://esa.un.org/unpd/wup/highlights/wup2014-highlights.pdf

USDA (2015) Working trees for Islands. Available at: http://nac.unl.edu/documents/workingtrees/ brochures/Working_Trees_Islands.pdf

van Leeuwen, B (2010) Dealing with urban diversity: promises and challenges of city life for intercultural citizenship. Polit Theor 38(5):631-657

Wezel A, Bender S (2003) Plant species diversity of home-gardens of Cuba and its significance for household food supply. Agrofor Syst 57(1):39-49

Wiskerke JSC (2015) Urban food systems. In: Cities and agriculture: developing resilient urban food systems, 1

World Health Organization (2002) WHO traditional medicine strategy 2002-2005. WHO, Geneva. Available at: http://www.wpro.who.int/health_technology/book_who_traditional_medicine_ strategy_2002_2005.pdf

Yamada M, Osaqui HML (2006) The role of homegardens in agroforestry development: lessons from Tome-Acu, a Japanese-Brazilian settlement in the Amazon. In: Tropical homegardens. Springer, Dordrecht, pp 299-316 